\title{
NUMERICAL ANALYSIS OF REINFORCED CONCRETE BEAM IN TWO- DIMENSIONAL FORM
}

Scientific paper / Znanstveni rad

Besim Demirović

(Received: 05 February 2019; accepted: 27 May 2019)

University of Tuzla, Faculty of Mining Geology and Civil Engineering, Associate professor

Corresponding author: besim.demirovic@untz.ba

Nedim Osmić

University of Tuzla, Faculty of Mining Geology and Civil Engineering, Assistant

\begin{abstract}
This paper presents a numerical analysis of a reinforced concrete beam in which the concrete and reinforcement are above the yield strength of the material. Further, the procedure for determining the relationship between the cross-sectional forces and the deformations of the layered cross-section of a rod is described. For a short rod with reduced stiffness of the El and EA cross-sections, a stiffness matrix with variable members is formed. The applicability of the proposed analysis method for the material nonlinearity in a beam calculation is demonstrated through a numerical example. The aim of the present paper is to show the flow of plastification and the loaddeformation of the system nodes. Finally, the results of the manual deformation calculation system are compared with the results from SCIA software.
\end{abstract}

Keywords: numerical analysis; material non-linearity; reinforced concrete beam; stiffness matrix

\section{NUMERIČKA ANALIZA NOSIVOSTI ARMIRANOBETONSKOG NOSAČA U RAVNINI}

Sažetak: U radu je pokazana numerička analiza armiranobetonskog nosača kada je ponašanje betona i armature iznad granice popuštanja materijala. Prikazan je postupak određivanja odnosa između presječnih sila i deformacija slojevitog poprečnog presjeka štapa. Za kratak štap s reduciranim krutostima poprečnog presjeka El i EA formirana je matrica krutosti štapa $s$ varijabilnim članovima. Aplikativnost predloženog postupka analize materijalne nelinearnosti pri proračunu nosača prikazana je u numeričkom primjeru. Cilj rada je prikazati tijek plastifikacije i odnose opterećenje - deformacija čvorova sustava. Na kraju su uspoređeni dobiveni rezultati manualnog proračuna deformacija sustava s rezultatima programskog paketa SCIA.

Ključne riječi: numerička analiza; materijalna nelinearnost; armiranobetonska greda; matrica krutosti 


\section{INTRODUCTION}

The development of the finite element method and numerical calculation methods have influenced the application of nonlinear analysis in construction calculations. With nonlinear analysis, it is important to know the behavior of the stress material described in the adopted models. Models of the theory of plasticity that describe the behavior of a material are shown in [1]. The Tresca-in model, Von Mises, Mohr-Columb, and Drucer-Prager models of the material behavior are used in the SCIA software package to control the results of the proposed calculation.

In [2] and [3], a mathematical formulation of the finite element is introduced, in which the nonlinear behavior of the material is included. In [2], the nonlinearity of a material was introduced under the von Mises yield criterion, whereas in [3], such nonlinearity is introduced through a model of the contact elements implemented between the finite elements.

The finite elements for the elastic behavior of a material are used in [4]. Nonlinearity is achieved by reducing the stiffness of the elements for a predefined plastic cross-sectional load. The rigidity of the elements is reduced until the forces in the two iterative steps become approximately equal. All approaches in nonlinear analysis of way constructions by numerical calculation methods, which solve nonlinear equations systems. The reason for this is that the behavior is based on conventional construction materials under a load to failure, which is a nonlinear process.

The behavior of conventional construction materials under load to failure is nonlinear. Material and geometric nonlinear problems are described through nonlinear equations, the solutions to which are complex. However, a small number of nonlinear equations have an analytic solution. Rational shows a numerical approach to a solution that can have a large number of numerical data, due to the large number of final elements needed in the discretization of the bearing system [5]. Contributions to an iterative solution to the problem of a large number of nonlinear equations in individual loading increments are described in [6] and [7].

Determining the static and deformation states, owing to the external load in the elastic region of a material behavior, is known as a Theory of Structures procedure based on the linear theory of elasticity. The area above the boundary of the elasticity of the connection between the stress and deformation becomes nonlinear. A nonlinear relationship between the stress and deformation causes a nonlinear connection between the force and displacement. By modeling the nonlinear relationship of the stress-deformation of the material into the calculation, a material non-linearity is introduced. The relationship between the stress and deformation of a material in the calculation is introduced by means of constituent equations. Elasticity theories use linear constituent equations, which have usage restrictions up to the limit of the material yield. After the yield limit, the expressions from which the solution to the problem of material nonlinearity arises should be adapted to the nonlinear state of the behavior of the material. In a stress-deformation $\left(\sigma_{s}-\varepsilon_{s}\right)$ diagram of the behavior of the reinforcement, there are three areas that are obtained by examining the tightening of the corresponding samples: the area of elasticity, part of the material flow, and curing to the maximum tensile stress. The dependence of the stress-deformation $\left(\sigma_{c}-\varepsilon_{c}\right)$ on concrete is generally nonlinear. In [8], the nonlinear stress-strain dependence of the concrete behavior in an analysis of the damage of reinforced concrete structures is used. The functional behavior of the materials is approximated using numerical methods, which are also used for the calculation. The nonlinear behavior of concrete and a reinforcement influences the change in stiffness of the support elements [9]. Therefore, it is necessary to define a diagram of the strength of reinforced concrete in the form of M-N-K. In determining the cross-sectional profile diagram, the following assumptions are adopted: a) The cross-sections remain flat and are governed along the axis of the carrier after deformation, b) concrete does not participate in the tensile load capacity, c) no slip occurs between the concrete and reinforcement, and the impact of the transversal forces on the load capacity is neglected, and d) the fork bending capacity is ignored. After defining the capacity of the cross-section of the staff, calculations of the transient forces and deformations take place through incrementally iterative procedures. The load is applied in steps from zero to the final value, in which a breakdown of the material of the characteristic section, or a loss of the stability of the element, occurs. 


\section{CAPACITY OF REINFORCED CONCRETE CROSS-SECTION}

In the analysis of the material nonlinearity of the system, the load capacity of the reinforced concrete section is determined based on the given combination of internal forces and the dependence of the stress-deformation of concrete $\left(\sigma_{c}-\varepsilon_{c}\right)$ and reinforcement $\left(\sigma_{c}-\varepsilon_{c}\right)$. By varying the bending moment and normal forces at the center of the cross-section, the deformation of the cross-section is determined.

The cross-section is loaded by the moment of bending around the axis and the normal force, which interact with the normal intensities of the section. A concrete behavior diagram was adopted in the form of polynomials, and the reinforcement was applied as a bilinear dependence of the stress-deformation, without taking into account the material safety coefficients (Figures 1e and 1f) [10]. In the combination of the bending moment and the normal force at each point of the section, normal stresses occur depending on the deformation of the cross-section. A solution to the problem of the cross-sectional load problem is sought out iteratively for the adopted load increment. The deformations of the section in the zeroth iterative step are described through the expansion $\varepsilon^{(0)}$ and curve $\kappa^{(0)}$, which are determined at the cross-sectional point according to the following expressions [11]:

$$
\varepsilon^{(0)}=\frac{N}{\mathrm{EA}_{\mathrm{i}}} ; \quad \kappa^{(0)}=\frac{\mathrm{M}_{\mathrm{i}}}{\mathrm{EI}_{\mathrm{i}}}
$$

where $E A_{i}$ is the axial stiffness of the cross-section of the rod, and $E I_{i}$ is the rigidity of its bending. The described stiffness of the section is determined based on the initial modulus of the material elasticity and the surface of the entire cross-section of the concrete and reinforcement. When nonlinear stress-strain relationships are used, a stiffness of the cross-section of the rod and an increase in the strain of the rod occur. In the $n$-th iterative step, the increments $\Delta \varepsilon$ and $\Delta K$ are of the following form:

$$
\Delta \varepsilon^{(n)}=\frac{\Delta N^{(n)}}{E_{t}^{(n)} \cdot A_{i}^{(n)}} ; \quad \Delta \kappa^{(n)}=\frac{\Delta M_{i}^{(n)}}{E_{t}^{(n)} \cdot I_{i}^{(n)}}
$$

where $E_{t}^{(n)} \cdot A_{i}(n)$ is the reduced axial rigidity of the cross-section of the rod in the nth iterative step, and $E_{t}^{(n)} I_{i}{ }^{(n)}$ is the reduced stiffness required to bend the cross-section of the rod in the $n$-th iterative step. The increment of the transient forces and the bending moment are determined through the following expression (3):

$$
\Delta N^{(n)}=N-N^{(n-1)} ; \quad \Delta M_{i}^{(n)}=M_{i}-M_{i}^{(n-1)}
$$

and the deformation size of the rod takes the following form (4):

$$
\varepsilon^{(n)}=\varepsilon^{(n-1)}+\Delta \varepsilon^{(n)} ; \quad \kappa^{(n)}=\kappa^{(n-1)}+\Delta \kappa^{(n)}
$$

To determine the surface Ai as well as the moment of inertia li and the cross-section, the concrete part and longitudinal reinforcement are pressed. When the stress changes, the tangent modulus of the material is changed by the height of the cross-section, depending on $\sigma$ and $\varepsilon$. In this case, the deformation quantities $\varepsilon$ and $k$ in expression (2) are defined by the functional dependence of the stress and deformation. The calculation of the deformation quantities with complex functions can be simplified by dividing the cross-section into layers. Each j-th layer of the cross-section at its center corresponds to the stress, deformation, and tangent modulus of the material [5]. 

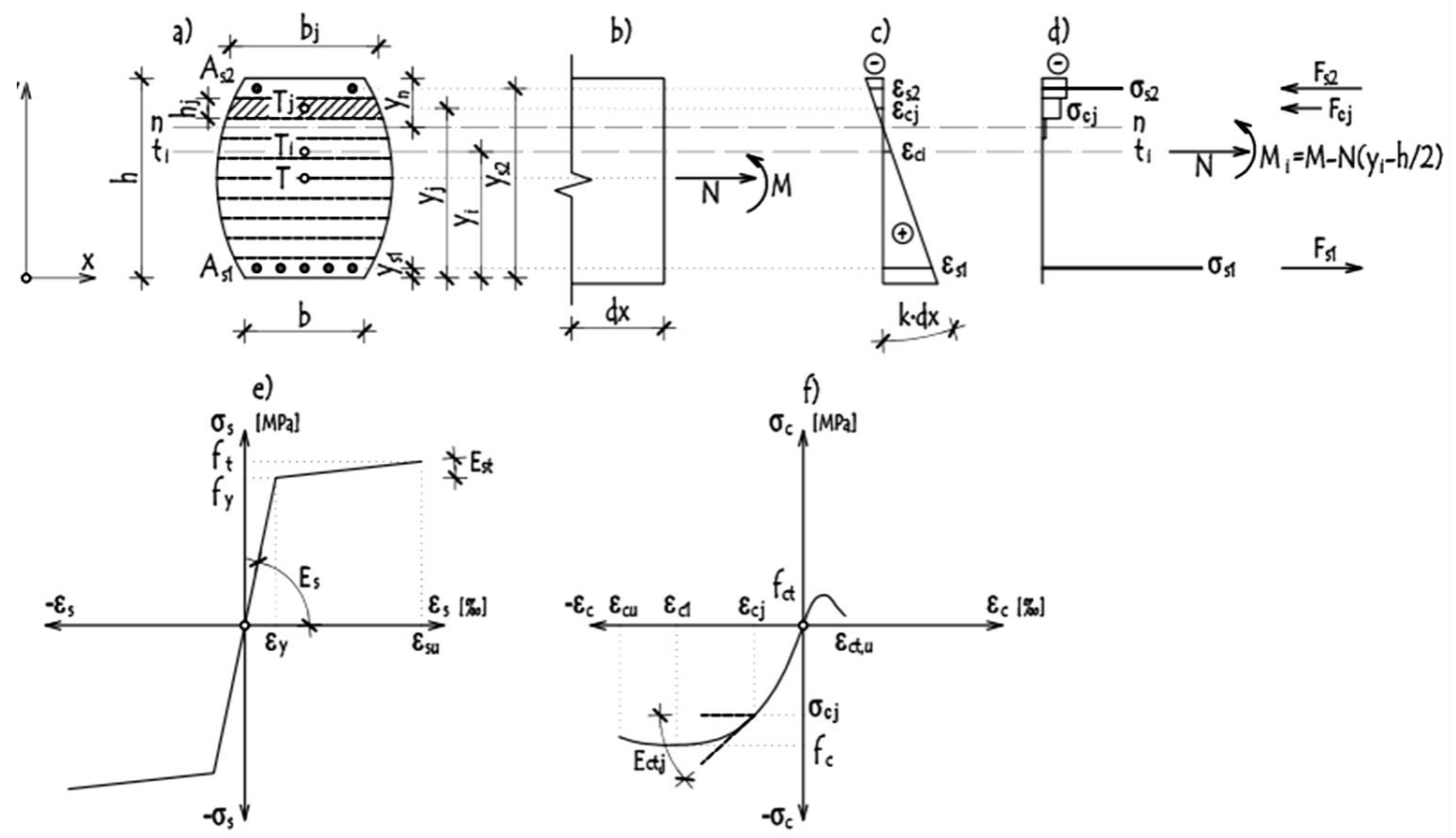

Figure 1 a) Cross section, b) elementary part of the rod length $d x, c$ ) distribution of the deformations, d) stresses and intensities, e) dependence diagram of the $\sigma_{c} \varepsilon_{c}$ armature, and f) a dependence diagram of $\sigma_{\mathrm{c}} \varepsilon_{\mathrm{c}}$ concrete

Static and geometric quantities are determined in relation to the ideal cross-sectional area of Ti. The steel used in the cross-section of the $\mathrm{E}_{\mathrm{t}} \mathrm{A}_{\mathrm{i}}$ and $\mathrm{E}_{\mathrm{t}} \mathrm{I}_{\mathrm{i}}$ rods are determined by layer in relation to the ideal focus on the terms:

$$
\begin{aligned}
& E_{t} A_{i}=\sum_{j} E_{c t, j} \cdot A_{j}+E_{s t} \cdot A_{s 1}+E_{s t} \cdot A_{s 2} \\
& E_{t} I_{i}=\sum_{j} E_{c t, j} \cdot A_{j}\left(y_{j}-y_{i}\right)^{2}+E_{s t} \cdot A_{s 1}\left(y_{i}-y_{s 1}\right)^{2}+E_{s t} \cdot A_{s 2}\left(y_{s 2}-y_{i}\right)^{2}
\end{aligned}
$$

Based on the deformation quantities $\varepsilon$ and $\mathrm{k}$, the distribution of the deformations along the height of the crosssection is as follows:

$$
\varepsilon_{\mathrm{cj}}=\varepsilon_{\mathrm{ci}}+\kappa \cdot\left(\mathrm{y}_{\mathrm{i}}-\mathrm{y}_{\mathrm{j}}\right) ; \quad \varepsilon_{\mathrm{s}}=\varepsilon_{\mathrm{ci}}+\kappa \cdot\left(\mathrm{y}_{\mathrm{i}}-\mathrm{y}_{\mathrm{s}}\right)
$$

Plastification of the section is based on the uniform properties of the materials [4]. For the deformation of the cross-sectional layers from the stress-deformation dependence diagram, the stress of the $\sigma_{\mathrm{cj}}$ layers of concrete and the $\sigma_{s}$ reinforcement is determined. Based on the strain of the concrete and reinforcement obtained, the forces $F_{c j}$ of the concrete layers and $F s$ of the reinforcement are determined. Under equilibrium of all forces in the axis $x$ axis, and using the sum of all moments around the x-axis at the center of the cross-section, the moments of bending $\mathrm{Mi}$ and force and $\mathrm{N}$ are obtained, which are unbalanced with the given intersecting forces. Owing to the increase in stress in the layers of concrete and reinforcement, there are changes in the static and geometric characteristics of the cross-section. In the next iterative step, the growth of the deformation quantities $\Delta \varepsilon$ and $\Delta K$, and the distribution of deformations along the height of the cross-section [12], are determined for the new position of the center of gravity and the static characteristics of the section. The deformation increment is determined through expression (2) owing to the difference between the given transient forces and the force in the (n-1) iterative step. The flow of the iterative process of the force balancing and deformation of the cross-section is shown in Figure 2. 
a)

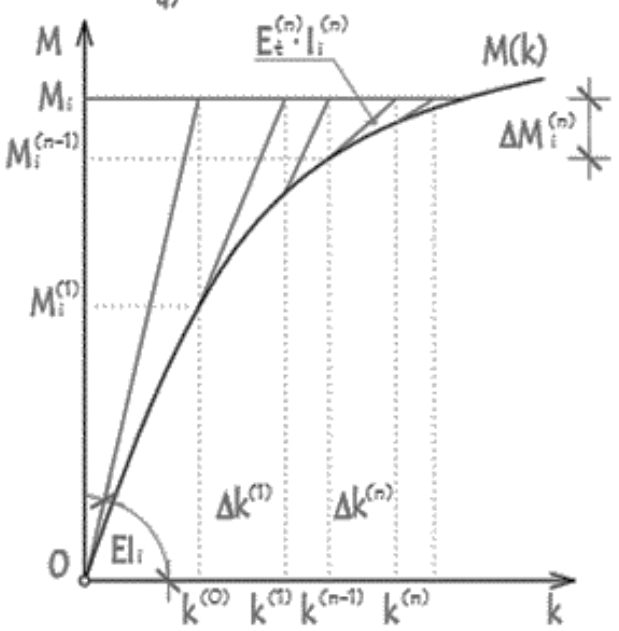

b)

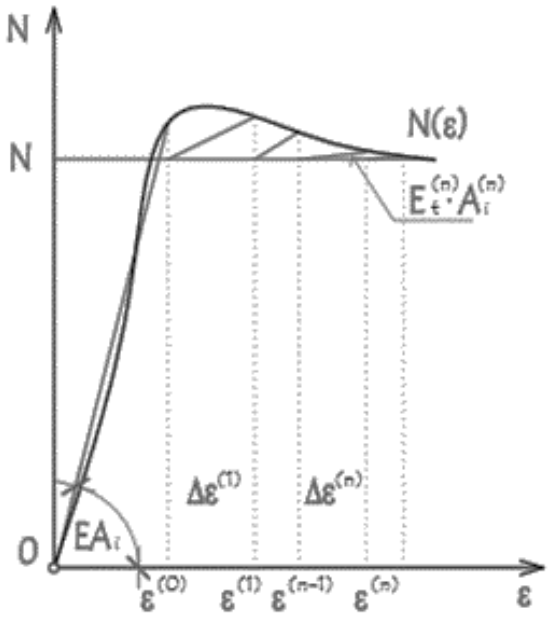

Figure 2 a) Flow of the iterative procedure of the relationship M-K and b) the iterative process of dependence $\mathrm{N}-\varepsilon$

\section{MODELING OF MATERIAL NONLINEARITY OF A ROD}

An analysis of the static and deformation sizes is carried out on a rod with the right axis exposed to a uniform amount of stress. The effect of the transverse forces on the movement of the rod is ignored. The rod has two nodes with three general displacements, totaling six degrees of movement and rotation at the ends of the rod [1]. Each generalized displacement [q] corresponds to the generalized force [R]. The relationship between generalized forces and displacement has the following form:

$$
[\mathrm{R}]=[\mathrm{k}] \cdot[\mathrm{q}]
$$

where $[k]$ is the matrix of the stiffness of the rod. The members of the rod stiffness matrix are constants of the rod dependent on EI, EA, and L. They are obtained as forces induced through a unit-generalized displacement, whereas the remaining generalized displacements are equal to zero [13]. In the nonlinear behavior of the material, the stiffness of the cross sections of the EI and EA rods are variable along the rod (Figures $3 b$ and $3 c$ ), which causes a change in the stiffness matrix of the members. If a stick is split into fewer elements, without major errors occurring in the results of the calculation, the same geometric and static characteristics of the cross-sections of the $a-b$ shape can be adopted:

$$
E_{t} A_{i, a b}=\frac{E_{t, a} \cdot A_{i, a}+E_{t, b} \cdot A_{i, b}}{2} ; \quad E_{t} I_{i, a b}=\frac{E_{t, a} \cdot I_{i, a}+E_{t, b} \cdot I_{i, b}}{2}
$$

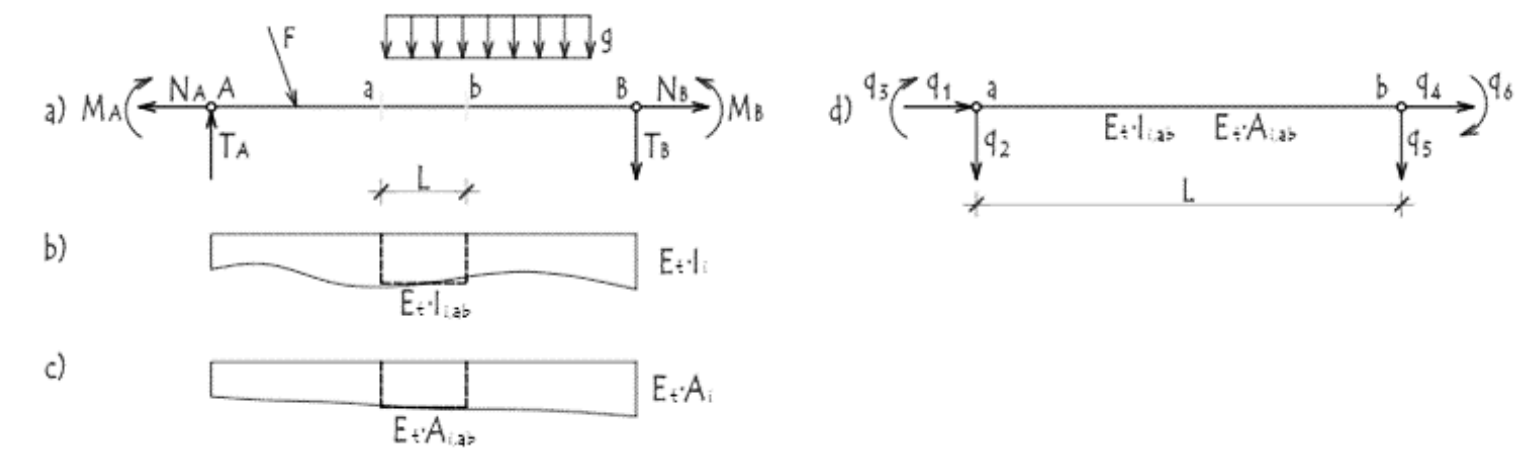

Figure 3 a) Rod A-B, b) change in stiffness of the bending section, c) change in axial stiffness of the section, and d) generalized movement of the $a-b$ rod 
The stiffness matrix of $a-b$ in accordance with the adopted generalized displacements shown in Figure $3 \mathrm{~d}$ has the following form:

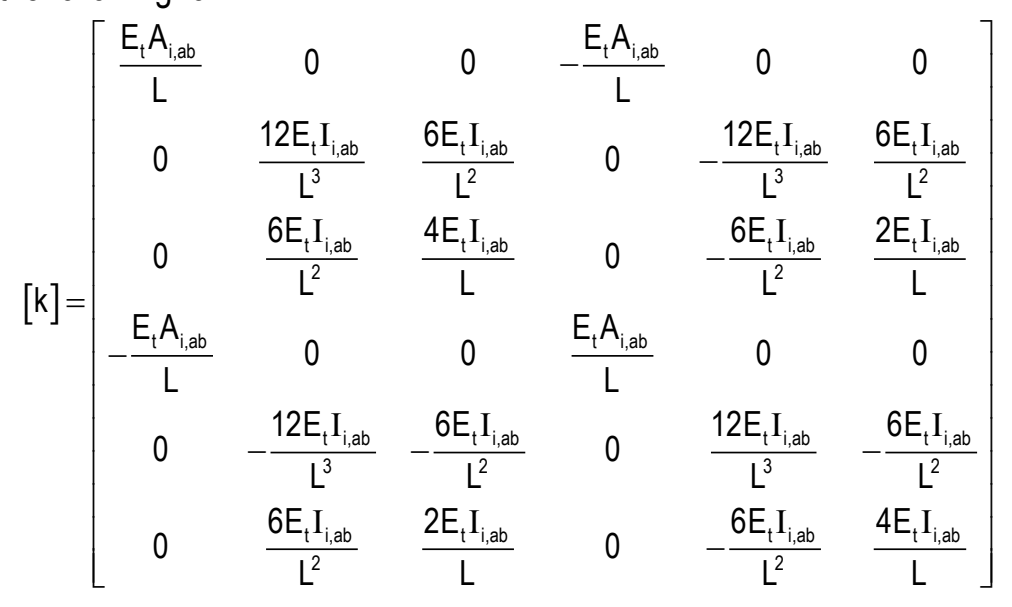

The equation of the equilibrium of nodes in matrix form is in the following form:

$$
[K]_{\text {nel }} \cdot[\mathrm{q}]+[\mathrm{Q}]=0
$$

where $[K]$ is a non-global material with a nonlinear matrix of the stiffness of the system, $[q]$ is a matrix deformation of the nodes, and $[Q]$ is a vector of the equivalent knot load. The solution to the system equations (10) is sought iteratively because the stiffness matrix of the system is nonlinear. During the iterative process, the changes in the static and geometric quantities of $\mathrm{E}_{\mathrm{t}} \mathrm{I}_{\mathrm{i}}, \mathrm{ab}, \mathrm{E}_{\mathrm{t}} \mathrm{A}_{\mathrm{i}}$, and ab are carried out according to the relations $\mathrm{M}$ $\mathrm{K}$ and $\mathrm{N}-\varepsilon$. The iterative procedure is carried out until reaching $\mathrm{m}$ iterations at which the stiffness of the rods in the system becomes approximately constant.

\section{EXAMPLE}

In the example used, the static-deformation state of the frame under a load to failure is analyzed. The input data for the material are as follows: $C 25 / 30$ concrete, $E_{c}=3 \times 10^{7} \mathrm{kN} / \mathrm{m}^{2}$; and $B 500 \mathrm{~N}$ reinforcement, $E_{s}=2 \times 10^{8} \mathrm{kN} / \mathrm{m}^{2}$. The stress-deformation dependence of the reinforcement was adopted in the form of a bilinear diagram (Figure $4 b)$, and for concrete as a third-degree polynomial (Figure 4c). For a non-linear analysis, the mechanical properties of the materials are adopted without safety coefficients. Based on the material behavior diagram, the balance of force and the moment of bending of the cross-section of the column and beam from the received initial value of the force to the breaking point were generated. It is assumed that the failure of the cross-section occurs when the stress is exceeded in one layer of the cross-section. The diagrams of this relationship are the bending-curvature sections of the section describing the change in stiffness of the cross-section of the rods. Describing the change in stiffness of the rod rods is advantageous by dividing the rods into smaller pieces. In the nodes, the generalized displacements in Figure 4a are numbered, approximating the deformation method. The initial load $q=16 \mathrm{kN} / \mathrm{m}$ is multiplied by the factor $f$ in five load increments until breaking. For each load increment, the calculation is carried out using an iterative Newton-Raphson tangent stiffness procedure. The force-displacement dependence is approximately linear to the load factor $f=1$. In this area, the reinforcement is located in an elastic area of behavior, and the concrete is partially coated. By increasing the load, which leads to the plastic behavior of the reinforcement and concrete, there is a significant decrease in the stiffness of the elements upon bending and an increase in strain in relation to the amount of stress. The first plastic joint appears from $f=1,55$ in node I. After the opening of the wrist in node I, the static system changes with a redistribution of the static influences. For a small load increment with factor $f=1,60$, plastic joints 2 and 3 are opened in nodes VIII and V. With the three joints, the system becomes a mechanism. The results of the budget are controlled using the SCIA software package, in which the elements are modeled in 2D [14]. 


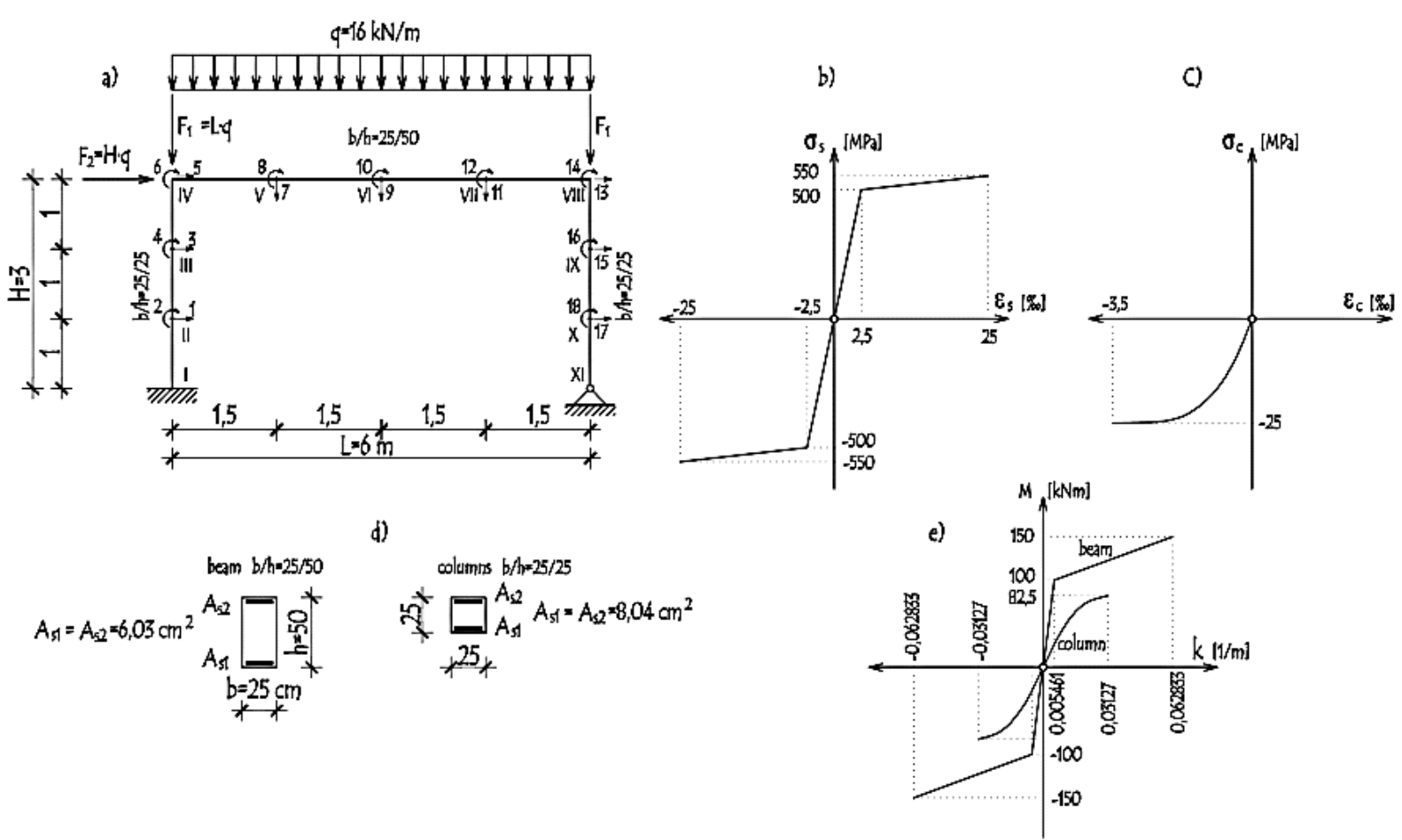

Figure 4 a) Example of a frame, b) dependency diagram $\sigma s-\varepsilon s$, c) dependency diagram $\sigma c-\varepsilon c$, d) crosssection of the rods, and e) dependency diagram M-K

For the normal force effect of the element, a change in the action of the bending moment is made in the crosssection of the rod until the limit value is reached. Each intensity of the bending moment corresponds to the deformation of the section. Based on the dependence of the bending moment and curvature, the stiffness in the bending of the cross-section of the rod was obtained, as shown in Tables 1 and 2.

Table 1 Numerical values of the change in stiffness and curvature of a beam cross-section depending on the bending moment

\begin{tabular}{ccccccccc}
\hline \multicolumn{8}{c}{ Beam $(\mathrm{N}=-20 \mathrm{kN})$} \\
\hline $\mathrm{M}[\mathrm{kNm}]$ & $\mathbf{0}$ & $\mathbf{5 0}$ & $\mathbf{7 5}$ & $\mathbf{1 0 0}$ & $\mathbf{1 2 5}$ & $\mathbf{1 3 5}$ & $\mathbf{1 4 0}$ & $\mathbf{1 5 0}$ \\
\hline $\mathrm{El}\left[\mathrm{kNm}^{2}\right]$ & 83002,80 & 18305,83 & 18215,58 & 18116,31 & 18007,71 & 1739,15 & 1529,24 & 932,98 \\
\hline $\mathbf{K}[1 / \mathrm{m}]$ & 0 & 0,002617 & 0,004026 & 0,005461 & 0,006928 & 0,012316 & 0,023955 & 0,062833 \\
\hline
\end{tabular}

Table 2 Numerical values of change in stiffness and curvature of a transverse pole depending on the bending moment

\begin{tabular}{cccccc}
\hline \multicolumn{6}{c}{ Column $(\mathrm{N}=-200 \mathrm{kN})$} \\
\hline $\mathbf{M}[\mathbf{k N m}]$ & $\mathbf{0}$ & $\mathbf{5 0}$ & $\mathbf{7 5}$ & $\mathbf{8 0}$ & $\mathbf{8 2 , 5}$ \\
\hline $\mathbf{E l}\left[\mathrm{kNm}^{2}\right]$ & 11006,80 & 4008,26 & 3734,13 & 3668,33 & 567,52 \\
\hline $\mathbf{K}[\mathbf{1 / m}]$ & 0 & 0,011577 & 0,021269 & 0,02393 & 0,031222 \\
\hline
\end{tabular}

The system stiffness matrix shown in Figure 4 has the following form: 


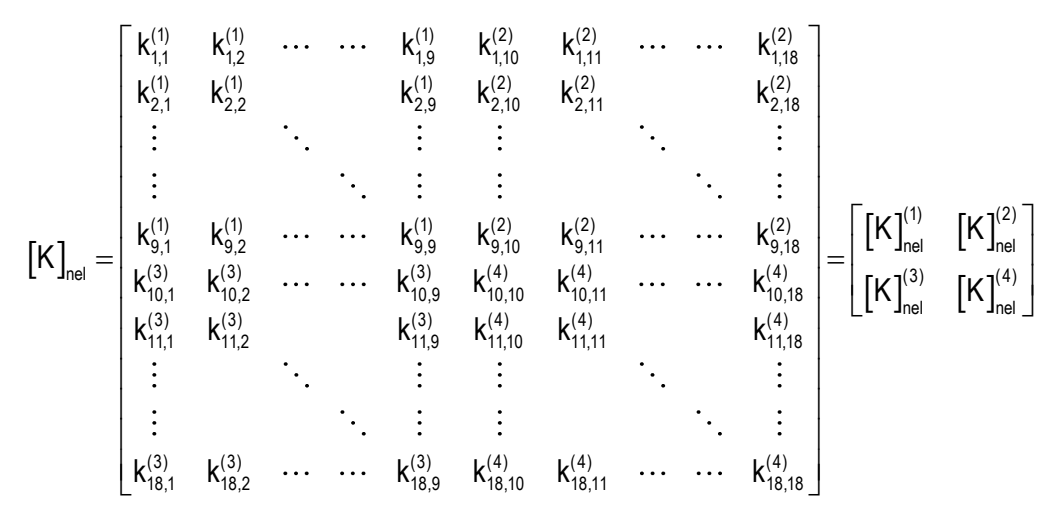

where the $[K]_{\text {nel }}{ }^{1},[K]_{n e l}^{2},\left.[K]_{n e l}\right|^{3},[K]_{n e l}{ }^{4}$ matrix blocks $[K]$ are not represented by the forms in (12), (13), (14), and (15), respectively.

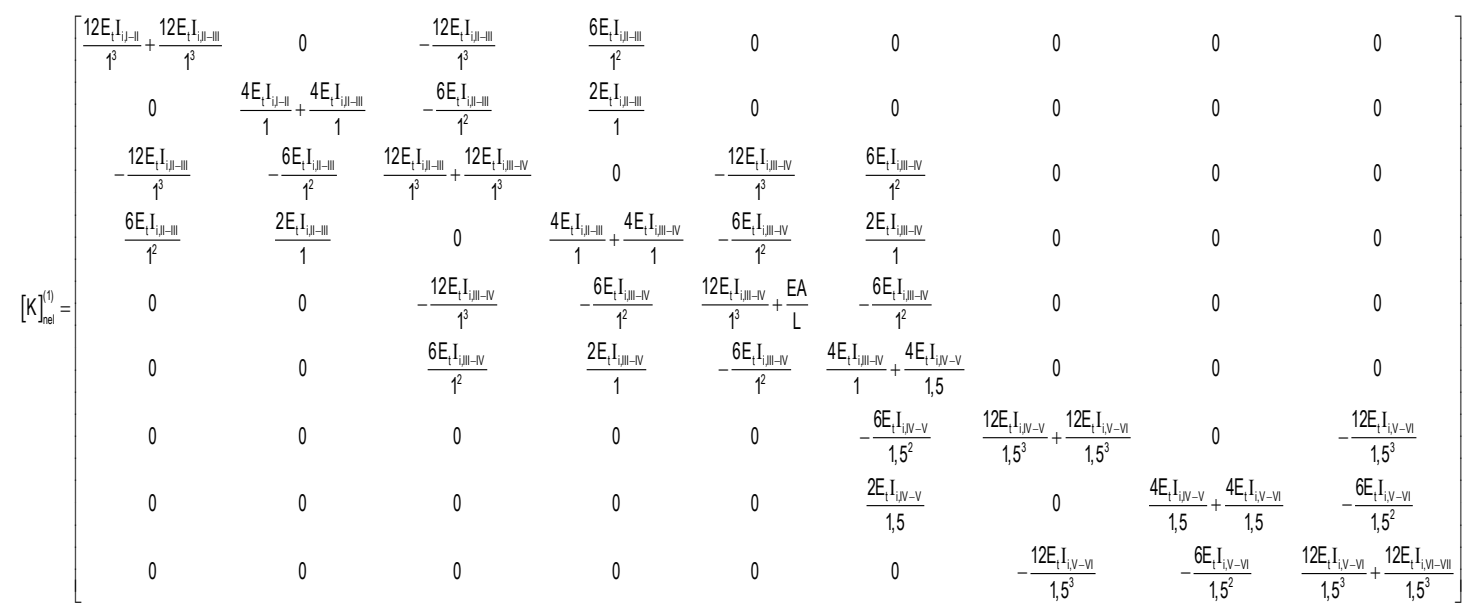

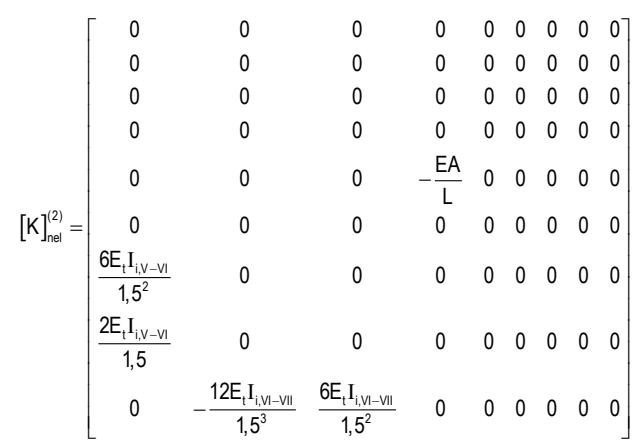

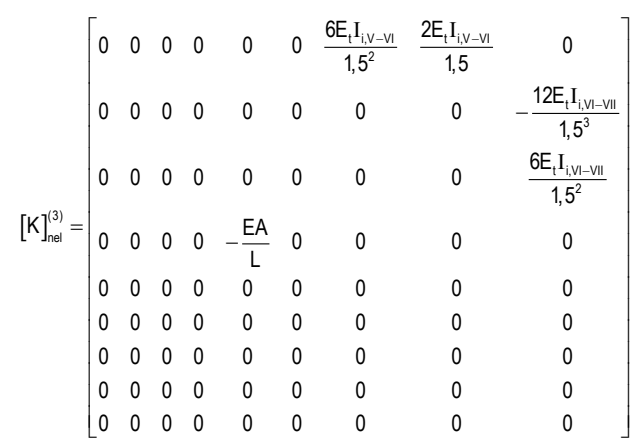

Demirović, B, Osmić, N 


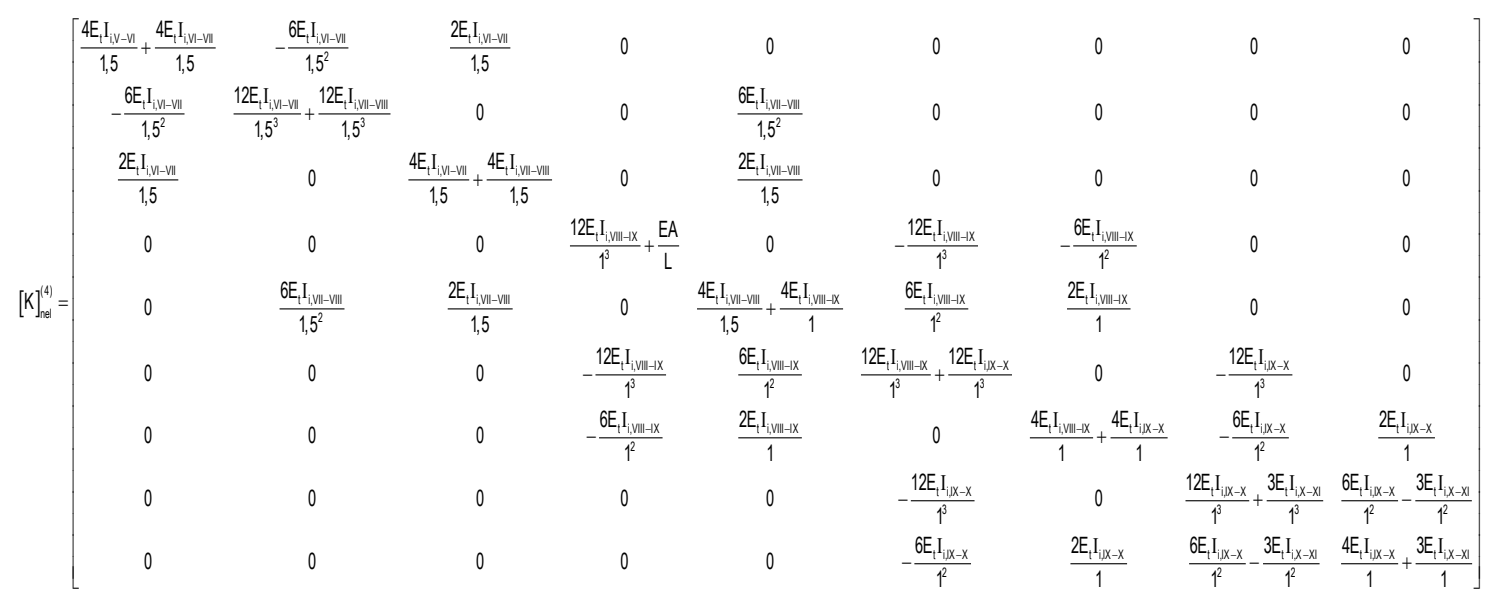

An equivalent nodal load vector is in the following form:

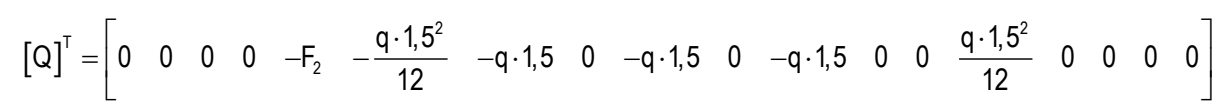

The results of the horizontal displacement calculation are shown in Figure 5.

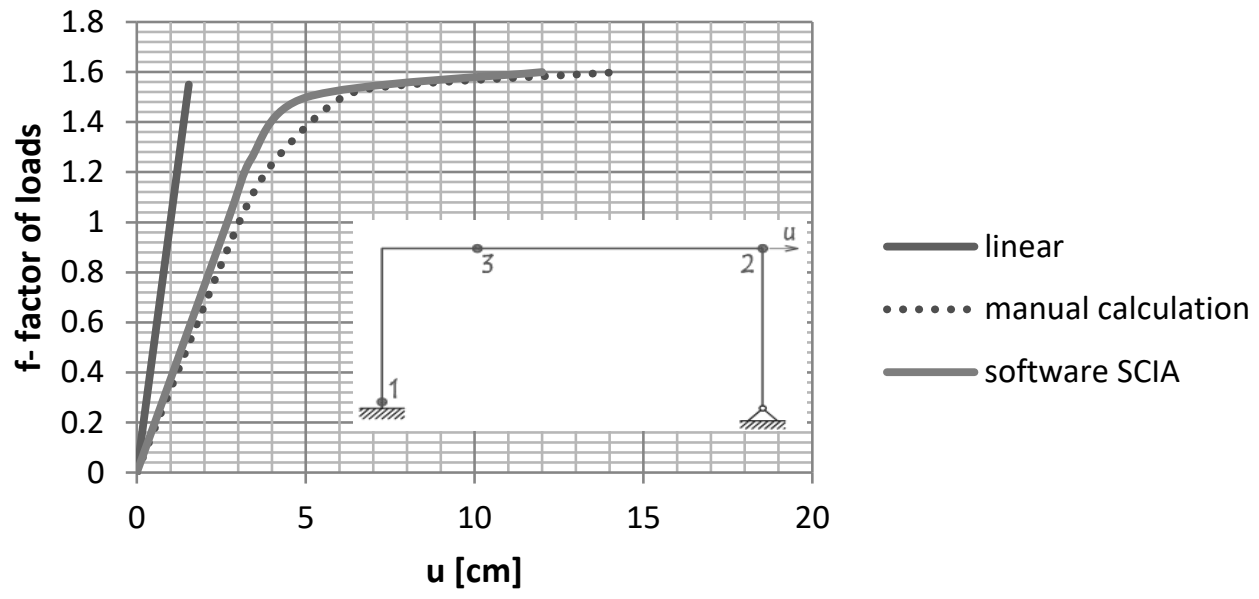

Figure 5 Results of horizontal displacement of a frame and the formation of plastic joints

Table 3 Numerical values of horizontal displacement of a frame Horizontal displacement of node IV [cm]

\begin{tabular}{ccccccc}
\hline $\mathbf{f}$ & $\mathbf{0}$ & $\mathbf{1}$ & $\mathbf{1 , 2 5}$ & $\mathbf{1 , 5 0}$ & $\mathbf{1 , 5 5}$ & $\mathbf{1 , 6 0}$ \\
\hline Linear & 0 & 0,99 & 1,24 & 1,49 & 1,54 & 1,60 \\
Manual calculation & 0 & 3,03 & 4,11 & 6,10 & 8,07 & 14,29 \\
Program SCIA & 0 & 2,68 & 3,37 & 5,04 & - & 12,26 \\
\hline
\end{tabular}

Figure 6 shows an incremental-iterative procedure for the calculation of the horizontal displacement of node IV. 


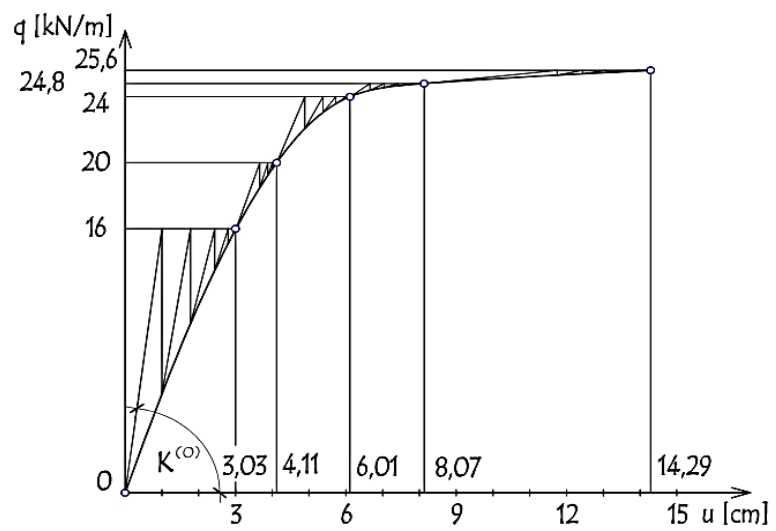

Figure 6 Incremental-iterative procedure of horizontal displacement of node IV

Table 4 Iterative calculation procedure of static-deformation nodal parameters

\begin{tabular}{|c|c|c|c|c|c|c|c|c|c|}
\hline \multirow{2}{*}{$\begin{array}{l}\text { Iteration } \\
\text { Nodes }\end{array}$} & \multicolumn{2}{|c|}{0.} & \multicolumn{2}{|c|}{1.} & \multicolumn{2}{|c|}{2.} & \multicolumn{2}{|c|}{3.} & \multirow[t]{2}{*}{4.} \\
\hline & \multicolumn{8}{|c|}{$\mathrm{Et} \cdot \mathrm{Ii}\left[\mathrm{kNm}{ }^{2}\right]$} & \\
\hline $\mathrm{I}$ & \multicolumn{2}{|c|}{11006,80} & \multicolumn{2}{|c|}{4651,02} & & & \multicolumn{2}{|c|}{3501,60} & 3208,84 \\
\hline II & \multicolumn{2}{|c|}{11006,80} & \multicolumn{2}{|c|}{4807,13} & & & \multicolumn{2}{|c|}{4390,25} & 4293,37 \\
\hline III & \multicolumn{2}{|c|}{11006,80} & \multicolumn{2}{|c|}{4878,79} & & & \multicolumn{2}{|c|}{4819,50} & 4848,23 \\
\hline IV & 11006,80 & 83002,80 & 11006,80 & 83002,80 & 4451,38 & 18311,66 & 4248,80 & 18311,66 & $4093,92 \quad 18311,66$ \\
\hline V & \multicolumn{2}{|c|}{83002,80} & \multicolumn{2}{|c|}{18311,66} & \multicolumn{2}{|c|}{18311,66} & \multicolumn{2}{|c|}{18311,66} & 18311,66 \\
\hline VI & \multicolumn{2}{|c|}{83002,80} & \multicolumn{2}{|c|}{18311,66} & & 1,66 & & 1,66 & 18311,66 \\
\hline VII & 830 & 2,80 & 183 & 1,66 & & 1,66 & & 1,66 & 18311,66 \\
\hline VIII & 83002,80 & 11006,80 & 83002,80 & 11006,80 & 18311,66 & 4205,47 & 18311,66 & 3636,70 & $18311,66 \quad 3302,23$ \\
\hline IX & 110 & 0,80 & &, 28 & & & & & 3975,02 \\
\hline$X$ & 110 & 6,80 & & 12 & & & & & 4510,24 \\
\hline $\mathbf{X I}$ & 110 & 6,80 & 110 & 6,80 & & 6,80 & & 6,80 & 11006,80 \\
\hline & & & & & & $1 / \mathrm{m}]$ & & & \\
\hline I & & & & & & & & & $-0,0135$ \\
\hline II & & & & & & & & & $-0,0055$ \\
\hline III & & & & & & & & & 0,0009 \\
\hline IV & 0,0037 & 0,0005 & 0,0051 & 0,0008 & 0,0075 & 0,0019 & 0,0075 & 0,0019 & $0,0077 \quad 0,0019$ \\
\hline V & & & & & & & & & 0,0036 \\
\hline VI & & & & & & & & & 0,0034 \\
\hline VII & & & & & & & & & 0,0012 \\
\hline VIII & $-0,0006$ & $-0,0043$ & $-0,0012$ & $-0,0084$ & $-0,0029$ & $-0,0129$ & $-0,0029$ & $-0,0129$ & $\begin{array}{ll}-0,0029 & -0,0129\end{array}$ \\
\hline IX & & & & & & & & & $-0,0080$ \\
\hline$x$ & & & & & & & & & $-0,0038$ \\
\hline$X I$ & & & & & & & & & 0,0000 \\
\hline & & & & & & $\mathrm{Vm}]$ & & & \\
\hline I & & & & & & & & & $-55,67$ \\
\hline II & & & & & & & & & $-25,56$ \\
\hline III & & & & & & & & & 4,56 \\
\hline IV & 40,27 & 40,27 & 32,99 & 32,99 & 32,25 & 32,25 & 34,02 & 34,02 & $34,67 \quad 34,67$ \\
\hline V & & & & & & & & & 66,58 \\
\hline VI & & & & & & & & & 62,50 \\
\hline VII & & & & & & & & & 22,42 \\
\hline VIII & $-47,68$ & $-47,68$ & $-65,31$ & $-65,31$ & $-55,45$ & $-55,45$ & $-53,74$ & $-53,74$ & $-53,67 \quad-53,67$ \\
\hline IX & & & & & & & & & $-35,78$ \\
\hline$x$ & & & & & & & & & $-17,89$ \\
\hline XI & & & & & & & & & 0,00 \\
\hline
\end{tabular}

In each iterative step, for a reduced stiffness to bend the cross-section of the rod an unbalanced load $\Delta M$ $(\Delta \mathrm{q})$ and deformation $\Delta \mathrm{k}(\Delta \mathrm{u})$ are obtained. The iteration procedure is continued until the contribution of the 
unbalanced load or displacement vectors is less than the set criteria. The results of the iterative procedure for changes in stiffness, curvature, bending moments, and displacements for the nodes of the system calculation are shown in Tables 4 and 5.

Table 5 Iterative procedure for calculation of nodal displacement

\begin{tabular}{cccccc}
\hline Iteration & 0. & 1. & 2. & 3. & 4. \\
\hline $\begin{array}{c}\text { Generalized } \\
\text { displacement }\end{array}$ & \multicolumn{5}{c}{ Nodal displacement [cm] } \\
$\mathbf{1}$ & 0,21 & 0,40 & 0,54 & 0,59 & 0,62 \\
$\mathbf{3}$ & 0,64 & 1,20 & 1,69 & 1,82 & 1,87 \\
$\mathbf{5}$ & 0,99 & 1,93 & 2,78 & 2,96 & 3,03 \\
$\mathbf{7}$ & 0,27 & 0,78 & 1,00 & 1,04 & 1,05 \\
$\mathbf{9}$ & 0,33 & 1,02 & 1,23 & 1,27 & 1,28 \\
$\mathbf{1 1}$ & 0,21 & 0,61 & 0,74 & 0,77 & 0,78 \\
$\mathbf{1 3}$ & 0,99 & 1,93 & 2,78 & 2,96 & 3,03 \\
$\mathbf{1 5}$ & 0,90 & 1,88 & 2,54 & 2,70 & 2,75 \\
$\mathbf{1 7}$ & 0,52 & 1,14 & 1,45 & 1,53 & 1,56 \\
\hline
\end{tabular}

\section{CONCLUSION}

This paper presented the procedure for a numerical calculation of a reinforced concrete beam after reaching the material yield limit. After the yield strength is reached, the stress-deformation and force-displacement become nonlinear. The problem of nonlinearity of the material affects the stiffness of the rods, which changes during the load increment.

In the nonlinear region of a material behavior, the stiffness of the section significantly decreases with respect to the stiffness in the elastic region. The decrease in the stiffness of the rods causes a redistribution of the transient forces and a greater increase in the deformation of the nodes in relation to the load.

By dividing into sections, it is possible to analyze the cross-sections that are loaded at the level of various geometric shapes, types, and quantities of the reinforcement. A concrete behavior diagram is given in the form of a polynomial, and the reinforcement in the form of a bilinear diagram. The dependence of the strain-deformation of concrete and reinforcement in other forms can be estimated.

The number of system nodes can be changed depending on the division of the rod into parts. The calculation results show the actual state of deformation through the load-bearing process, based upon which the load capacity and functionality of the structure can be seen. The calculation model is applicable in the analysis of the earthquake resistance of a structure. From the calculation, it can be concluded that there is a failure of individual nodes and the appearance of joints, which does not mean a failure of the entire system. A collapse of the carriage occurs when the joint that causes the mechanism of the system opens. The advantage of the illustrated calculation is that the deformations of the system can be controlled after the opening of the joint caused by the mechanism because the condition of the cross-sectionality is shown in relation to the bending moment-curvature of the cross section for $\mathrm{N} \neq 0$.

Based on the described method of a nonlinear analysis of reinforced concrete structures, it is possible to analyze the damaged elements of the system after a fire. In damaging the structure, the material of the system elements changes the mechanical properties. In doing so, the characteristics of the concrete and reinforcement can be taken into account and the limit load is determined through an incrementally iterative process.

By comparing the load and displacement ratio, it can be concluded that there is a greater displacement of the beams with a reduced stiffness of the rods. The presented numerical calculation method provides a real distribution of transient forces taking into account the material nonlinearity of the individual parts of the beam. 


\section{References}

[1] Zienkiewicz, O. C.; Taylor, R. L. 2000: The Finite Element Method, Butterworth-Heinemann, Oxford

[2] Jiang, Y.; Wang, C. 2008: On Teaching Finite Element Method in Plasticity With Mathematica, Computer Applications in Engineering Education, 16, pp. 233-242, https://doi.org/10.1002/cae.20135

[3] Smoljanović, H.; Živaljić, N.; Nikolić, Ž. 2013: Nonlinear analysis of engineering structures by combined finitediscrete element method, Građevinar, 65 (4), pp. 331-344

[4] Trogrlić, B.; Mihanović, A. 2011: Nelinearni model prostornih konstrukcija s primjenom na potresnu otpornost, Građevinar, 63 (2), pp. 111-124 (in Croatian)

[5] Mihanović, A.; Marović, P.; Dvornik, J. 1993: Nelinearni proračuni armirano betonskih konstrukcija, Društvo hrvatskih građevinskih konstruktora, Zagreb (in Croatian)

[6] Rezaiee-Pajand M.; Afsharimoghadam H. 2017: Optimization Formulation for Nonlinear Structural Analysis, International journal of optimization in civil engineering, 7 (1), pp. 109-312

[7] Saffari, H.; Mansouri, I.; Bagheripour, M.H.; Dehghani, H. 2012: Elasto-Plastic Analysis of Steel Plane Frames Using Homotopy Perturbation Method, Journal of Constructional Steel Research, 70, pp. 350-357. https://doi.org/10.1016/i.jcsr.2011.10.013

[8] Orešković, M.; Klimenko, L.; Aniskin, A.; Kozina, G. 2018: Analysis of Damaged Concrete Columns of Circular Cross-Section, Tehnički vjesnik - Tehnical Gazette, 25 (2), pp. 337-343, https://doi.org/10.17559/TV20160621085905

[9] Maglajlić, Z. 2008: Metoda relaksacije - Linearni i nelinearni problemi, Štamparija Fojnica, Fojnica (in Bosnian)

[10] Anđelić, M. 2005: Građevna statika II, Građevinski fakultet Sveučilišta u Zagrebu, Zagreb (in Croatian)

[11] Maglajlić, Z. 1995: Nelinearna analiza okvirnih konstrukcija metodom relaksacije, Unisoft Beograd, Beograd (in Serbian)

[12] Demirović, B.; Požegić, Z.; Memić, M. 2015: Numeričko modeliranje materijalne nelinearnosti štapa, 10th International Scientific Conference RIM Dubrovnik, 10 (72), pp. 415-420 (in Croatian)

[13] Sekulović, M. 2005: Teorija linijskih nosača, Građevinska knjiga, Beograd (in Serbian)

[14] SCIA Software: Structural Analysis and Design Software, Scia.net

Please cite this article as:

Demirović, B.; Osmić, N.: Numerical analysis of reinforced concrete beam in two-dimensional form, Electronic Journal of the Faculty of Civil Engineering Osijek-e-GFOS, 2019, 18, pp. 36-47, https://doi.org/10.13167/2019.18.4 